\title{
Citation Method and Abbreviated Titles
}

Wherever a citation in round brackets appears in the body of the main text (e.g., RD, 473), it invariably refers to Taha's work. Transliterated phrases and passages quoted from Taha's writings will appear, with relevant page citations, in the endnotes, along with all other references. Works that have not been extensively analyzed are cited with unabbreviated titles.

AD: Al-'Amal al-Dini wa-Tajdìd al-'Aql [Religious Praxis and the Renewal of Reason], 4th ed. Casablanca: al-Markaz al-Thaqāfī al-'Arabī, 2006.

HAF: al-Haqq al-'Arabi fil-Ikhtilāf al-Falsafī [The Arab Right to Philosophical Difference], 2nd ed. Casablanca: al-Markaz al-Thaqāēi al-`Arabī, 2006.

HIF: al-Haqq al-Islāmī fil-Ikhtilāf al-Fikrī [The Islamic Right to Intellectual Difference]. Casablanca: al-Markaz al-Thaqāfī al-'Arabī, 2005.

KNN: "Kayfa Nujaddid al-Naẓar fil-Turāth" ["How Do We Rethink Tradition"], in $S M, 41-57$.

RD: Rūh al-Dīn: Min Dịq al-'Almāniyya ilā Si'at al-I'timāniyya [The Spirit of Religion:

From the Narrowness of Secularism to the Capaciousness of Trusteeship]. Casablanca: al-Markaz al-Thaqāfī al-`Arabī, 2012.

RH: Rūḥ al-Hadātha: al-Madkhal ilā Ta'sīs al-Hadātha al-Islāmiyya [The Spirit of Modernity: A Prolegomenon to Laying the Foundations of Islamic Modernity]. Casablanca: al-Markaz al-Thaqāfī al-`Arabī, 2006. 
SA: Su'āl al-Akhlāq: Musāhama fil-Naqd al-Akhlāqì lil-Hadātha al-Gharbiyya [The Question of Ethics: A Contribution to an Ethical Critique of Western Modernity]. Casablanca: al-Markaz al-Thaqāfī al-'Arabī, 2000.

SM: Su'âl al-Manhaj: Fì Ufuq al-Ta'sīs li-Unmūdhaj Fikrī Jadīd [The Question of Method: Toward a New Intellectual Paradigm]. Edited by Raḍān Marhūm. Beirut: al-Mu'assasa al-'Arabiyya lil-Fikr wal-Ibdāc, 2015.

SU: Su'āl al-'Unf: Bayna al-I'timāniyya wal-Hiwäriyya [The Question of Violence: Between Trusteeship and Dialogue]. Beirut: al-Mu'assasa al-'Arabiyya lil-Fikr wal-Ibdāc, 2017.

TM: Tajdìd al-Manhaj fì Taqwim al-Turāth [Renewal of Method for the Rectification of Tradition], 3rd ed. Casablanca: al-Markaz al-Thaqāfĩ al-'Arabī, 2007.

UNIT: "Al-Ușūl al-Naẓariyya al-Takāmuliyya fil-Ishtighāl bil-Turāth" ["The Foundations of a Theory of Integral Unity in the Study of Tradition"], in SM, 59-70. 